\title{
Infectious salmon anaemia virus infection of Atlantic salmon gill epithelial cells
}

\author{
Simon Chioma Weli ${ }^{1 *}$, Maria Aamelfot ${ }^{1}$, Ole Bendik Dale ${ }^{1}$, Erling Olaf Koppang ${ }^{2}$ and Knut Falk
}

\begin{abstract}
Infectious salmon anaemia virus (ISAV), a member of the Orthomyxoviridae family, infects and causes disease in farmed Atlantic salmon (Salmo salar L.). Previous studies have shown Atlantic salmon endothelial cells to be the primary targets of ISAV infection. However, it is not known if cells other than endothelial cells play a role in ISAV tropism. To further assess cell tropism, we examined ISAV infection of Atlantic salmon gill epithelial cells in vivo and in vitro. We demonstrated the susceptibility of epithelial cells to ISAV infection. On comparison of primary gill epithelial cell cultures with ISAV permissive fish cell cultures, we found the virus yield in primary gill epithelial cells to be comparable with that of salmon head kidney (SHK)-1 cells, but lower than TO or Atlantic salmon kidney (ASK)-II cells. Light and transmission electron microscopy (TEM) revealed that the primary gill cells possessed characteristics consistent with epithelial cells. Virus histochemistry showed that gill epithelial cells expressed 4-O-acetylated sialic acid which is recognized as the ISAV receptor. To the best of our knowledge, this is the first demonstration of ISAV infection in Atlantic salmon primary gill epithelial cells. This study thus broadens our understanding of cell tropism and transmission of ISAV in Atlantic salmon.
\end{abstract}

Keywords: ISAV, Cell tropism, Sialic acid receptor, Gill epithelial cells

\section{Background}

Infectious salmon anaemia (ISA) in Atlantic salmon (Salmo salar L.) is a World Organisation for Animal Health (OIE) notifiable disease. Clinical ISA is characterized by circulatory disturbances including anaemia, gill pallor, ascites, intestinal congestion, liver and spleen enlargement and petechial haemorrhage of the skin and visceral organs [1]. The disease was first recognized in Norway in 1984, but has been subsequently identified, with high associated mortalities, in farmed Atlantic salmon in Europe, and North- and South America [2-7].

ISA is caused by the infectious Salmon Anaemia Virus (ISAV), the only member of the genus Isavirus in the family Orthomyxoviridae. The virus has been characterized morphologically [8-11], bio-physiochemically [9,12-15] and genomically [16-23]. However, the pathogenesis of ISAV is not clear and in particular, the site/s of entry into Atlantic salmon remains unknown. In cell culture, ISAV replication has been demonstrated only in SHK-1, ASK-II,

\footnotetext{
* Correspondence: Simon.Weli@vetinst.no

${ }^{1}$ Norwegian Veterinary Institute, Ullevålsveien 68, PO Box 750 Sentrum, Oslo N-0106, Norway

Full list of author information is available at the end of the article
}

TO and Atlantic salmon (AS) cells, although replication of some Canadian ISAV isolates has also been demonstrated in Chinook salmon embryo (CHSE)-214 cells [24-27]. With the exception of AS and CHSE-214, all these cellcultures are derived from Atlantic salmon adherent head kidney macrophages and mitogen-stimulated peripheral blood leucocytes [24,25,27], and will not, therefore, reveal the virus entry-site into the Atlantic salmon.

The gills, comprising the vasculature and surrounding epithelia $[28,29]$, provide a key interface between the fish and the environment, acting as site for gas exchange, body fluid regulation and waste excretion [30]. As they filter large amounts of water they offer a suitable target for invading infectious agents. While RT-PCR detection of ISAV on whole gill preparations has suggested the gills as an entry-site for ISAV infection [31], in vivo studies have only reported ISAV infection within endothelial cells and leucocytes $[11,32,33]$. We showed previously that gill and hind-gut mucosal epithelial cells express the ISAV 4-O-acetylated sialic acid receptor on the cell surface [33], indicating the potential for ISAVinfection of epithelial cells. High prevalences of ISAV positive gills by RT-PCR, have been documented, both 
for low pathogenic ISAV-HPR0 cases in the Faroe Islands [34], and in high pathogenic ISA outbreaks in Norway [35]. However, analysis of whole gill samples, comprising different cell types, does not allow identification of the specific cell type infected with the virus, or prove the gill to be the entry-site for infection.

If the gill does represent an entry site for ISAV, the virus must penetrate the protective mucosal epithelial barrier. Possible mechanisms include transcytosis, infection of tissue macrophages orchestrated by antigen sampling cells (i.e. dendritic cells) or by direct infection of the epithelial cells [36]. Interestingly, mammalian and avian orthomyxoviruses use upper and lower respiratory epithelial cells (analogous to gill epithelial cells) for replication $[37,38]$.

Different approaches have been used to study viral cell tropism. Some studies have used immunohistochemistry [39] or in situ hybridization during natural or experimental infection. Others have used ex-vivo organ cultures $[40,41]$ or specialized, immortalized cell lines. The study of viral disease in Atlantic salmon is made difficult by the limited availability of specific cell cultures. Thus, in such cases, utilisation of primary cell cultures closely representing the in vivo situation can be rewarding $[42,43]$.

In the present study we examined ISAV infection of gill epithelial cells following emersion (bath) challenge and by infection of primary gill epithelial cell cultures. We demonstrated the susceptibility of Atlantic salmon gill epithelial cells to ISAV both in vivo and in vitro. When compared with ISAV- permissive fish cell lines, primary epithelial cells showed virus yields comparable to SHK-1 cells.

\section{Results and discussion}

Previous studies have demonstrated ISAV receptor expression on gill mucosal epithelial cells [33] and high prevalences of ISAV positive gills by RT-PCR [31,34], suggesting ISAV infection of gill cells. However, such infections have not been confirmed at the cellular level. In the present study, we performed in vivo immersion challenge experiments to investigate ISAV infection and cell tropism in Atlantic salmon gills and in vitro experiments utilising primary gill epithelial cells.

\section{ISAV infection of gill epithelial cells following immersion challenge}

Previously, we identified, by immunohistochemistry on formalin-fixed paraffin-embedded tissue sections, ISAV infected endothelial cells 8 d.p.i. The ISAV-receptor was localized on gill endothelial and epithelial cells [33]. Only minor pathological changes were observed at autopsy and on histological examination of Atlantic salmon bath challenged with ISAV. Pathological changes included haemorrhage in the skin and eye, sparse ascites, blood stasis in the anterior kidney and minor haemophagocytosis in the spleen. Analysis of gill tissue sections sampled at 8 d.p.i. revealed sparse presence of individual ISAV-positive gill epithelial cells (Figure 1), but not at other time points. Positive endothelial cells were also detected at day 8 p.i., but at low levels. The observation of ISAV-positive gill epithelial cells at day 8 p.i, but not at later time points, indicates that ISAV infects gill epithelial cells at an early stage in the infection, and points to the gill as a possible site of entry and primary replication as previously suggested [31]. The low number of positive cells supports the notion that the gill epithelial cell is not the main target cell for ISAV, which is in agreement with our recent finding that endothelial cells are the main targets for ISAV [33]. In addition, it does not exclude the possibility of other important infection routes, and/or that we have not sampled intensively enough to reveal possible rapid and transient epithelial infection.

\section{Isolation of primary gill cells from juvenile Atlantic salmon}

To further explore ISAV infection of gill epithelial cells and to corroborate data from in vivo experiments, we carried out a series of in vitro experiments using primary gill epithelial cells isolated from juvenile Atlantic salmon. Culture morphology was assessed at varying incubation time points by phase contrast microscopy and immunofluorescence techniques. At $24 \mathrm{~h}$, small colonies of cells had established contact with the substrate, forming tight clusters of 10 to 60 cells. By 48 to $72 \mathrm{~h}$ when culture medium was changed and unattached cells removed, the colonies had expanded 2-fold (Figure 2a). Cells spread faster and projected upwards from the substrate when seeded abundantly $\left(4.0 \times 10^{5}\right.$ cells $\left./ \mathrm{cm}^{2}\right)$, but when seeded more sparsely $\left(2.0 \times 10^{5}\right.$ cells $\left./ \mathrm{cm}^{2}\right)$, they appeared flattened and the time taken to form a complete monolayer was extended. Viability of cells was demonstrated by trypan-blue exclusion [44] of more than $90 \%$ of the cells at day 7 post isolation, indicating prolonged viability (data not shown).

\section{Epithelial origin of isolated primary gill cells}

To confirm that the isolated primary gill cells were of epithelial origin, immunocytochemical staining with an epithelial-specific cytokeratin marker was performed. Cells consistently stained positive for cytokeratin, and showed little contamination with other cell types (Figure 2b), indicating that the cultured gill epithelial cells were largely monomorphic. Using transmission electron microscopy (TEM), we assessed 7-day-old cultures for epithelial characteristics. We found tight junctions, nuclei and cytoplasmic organelles including endoplasmic reticulum (Figure 2c-f), all features consistent with epithelial cells. We were however, unable to localize desmosomes. A possible explanation 


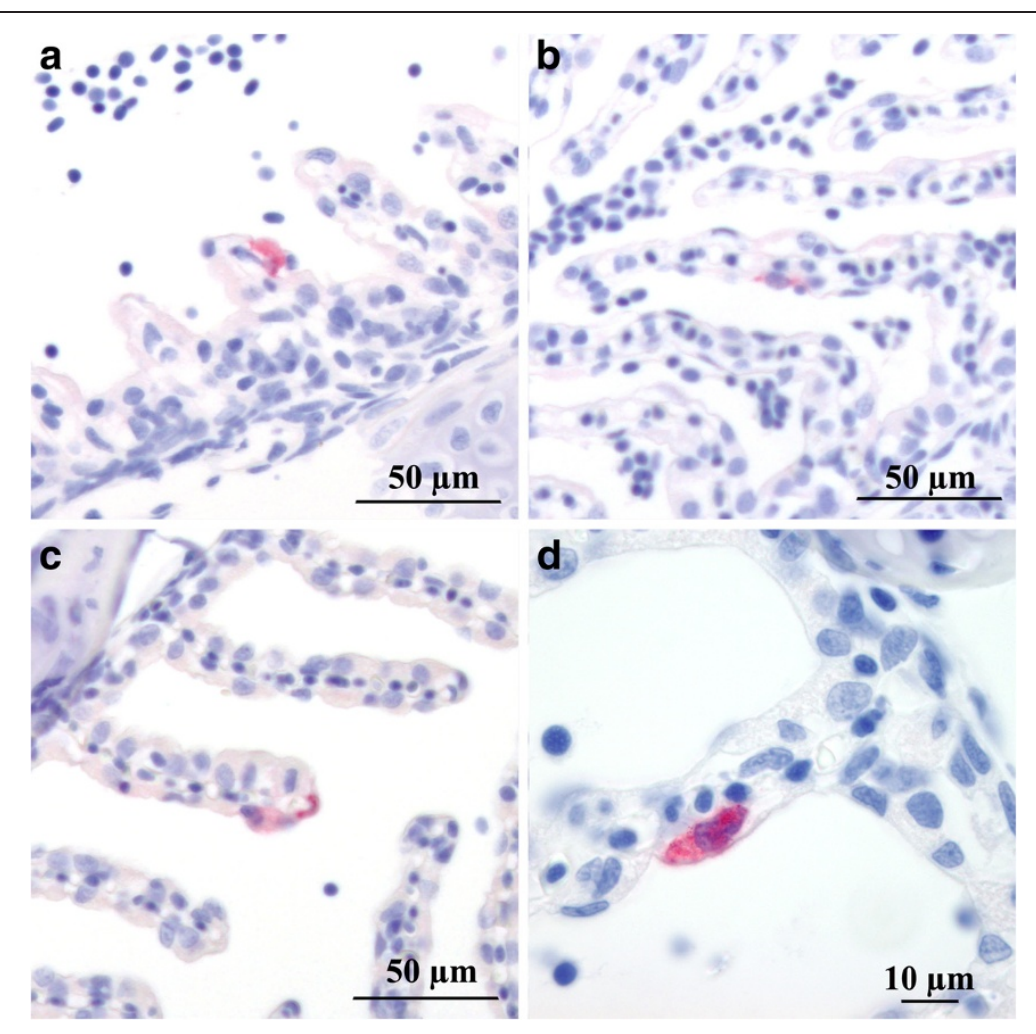

Figure 1 Immunohistochemical detection of ISAV in formalin fixed paraffin embedded tissue sections from four experimentally immersion challenged Atlantic salmon. Positive epithelial cells are red.

for this may lie in our sample preparation, as some studies indicate that a freeze fracture technique is required to characterize complete regions of tight membrane-tomembrane contact [45].

\section{Detection of ISAV 4-O-acetylated sialic acid receptor on primary gill epithelial cells}

Species preference and tissue tropism are critical for ISAV transmission and infection. As documented previously, ISAV binds 4-O-acetylated sialic acid receptors. Recent evidence gathered by virus histochemistry on Atlantic salmon tissue using ISAV antigen as a probe, indicated that 4-O-acetylated sialic acid receptors are expressed on the surface of host cells; including endothelial cells as well as gill- and hind gut mucosal epithelial cells [15,33]. To assess the potential infection- and tissue tropism of ISAV for gill epithelial cells, we investigated the presence/absence of sialic acid receptors on non-infected primary gill epithelial cell isolates by virus histochemistry. Expression of the ISAV receptor on gill epithelial cells was confirmed (Figure 3a), suggesting that ISAV may have the potential to infect and replicate in gill epithelial cells. The primary epithelial cells were washed extensively to remove serum and other culture media components prior to incubation with antigen. However, some of the positive staining might be due to non-specific binding of antigen to cell surface- associated components rather than to integral membrane glycoproteins. To further clarify this we performed control experiments that included exposing the gill epithelial cells to a mild alkaline solution; a well-established method for de-O-acetylation of sialic acids [46]. This treatment completely abolished the staining, confirming the specificity of the reaction (Figure $3 \mathrm{~b}$ ).

\section{ISAV infection of primary gill epithelial cells}

We have demonstrated ISAV infection of epithelial cells following in vivo immersion challenge (Figure 1). We have also shown that primary gill cell cultures possess epithelial characteristics (Figure 2) and express 4-Oacetylated sialic acid receptors (Figure 3 ), which correlates with previous reports on 4-O-acetylated sialic acid expression [15,33]. In order to explore possible ISAV-gill epithelial cell tropism, we performed in vitro ISAV infection of gill epithelial cells. We found that ISAV readily infected epithelial cells as shown by IFAT (Figure 4a). No viral antigen was detected in mock-infected cells (Figure $4 \mathrm{~b}$ ). The positive staining and receptor binding are consistent with previous reports from endothelial cells $[13,33]$. To the best of our knowledge, this is the first report demonstrating ISAV infection in epithelial cells and provides new insight into in vivo ISAV replication in epithelial cells. 

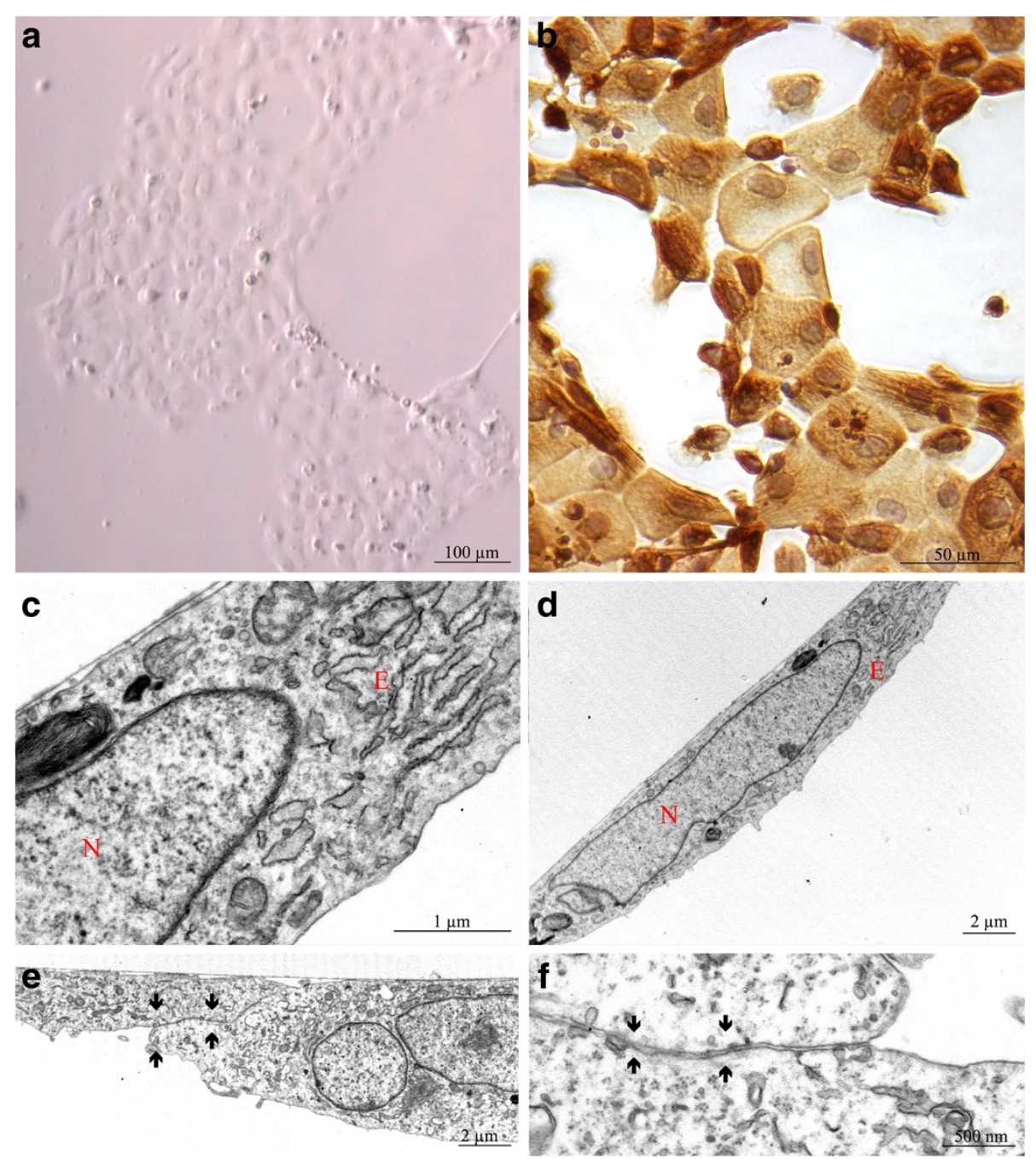

Figure 2 Atlantic salmon primary gill epithelial cells. (a) Photomicrograph of unstained representative field with typical epithelial cell morphology at $72 \mathrm{~h}$ post isolation. (b) Anti-cytokeratin immunostaining (AE1/AE3) $72 \mathrm{~h}$ post isolation. (c-f) Transmission electron microscopy micrographs of monolayer with large nuclei (N), cytoplasmic organelles including endoplasmic reticulum (E) and tight junctions (arrows). $\mathbf{c}$ is a magnification of $\mathbf{d}$.

\section{ISAV replication assay}

As the results from in vivo experimental infection correlated with in vitro infection, we compared viral particle production in primary gill epithelial cells with ASK-II, SHK-1 and TO cells. ASK-II, SHK-1 and TO cells are commonly used for both research and routine diagnostics and are permissive to ISAV $[8,25,27]$. We found virus yields in gill epithelial cells comparable to SHK-1 cells, 10-fold lower than TO cells and 100-fold lower than ASK-II cells (Table 1). This study demonstrates not only the capacity of ISAV to replicate in primary gill epithelial cells, but also that virus produced in the primary epithelial cells replicated in ASK-II cells that was used for virus titration. The virus yield obtained in the present study from primary gill cultures is clearly lower than that determined on ISAV infected SHK-1 $\left(10^{6}\right.$ to $\left.10^{7}\right)$ [9] and TO $\left(10^{7.8}\right.$ to $\left.10^{9.1}\right)$ [27] cells. However, virus supernatants in our study were harvested on day 4 p.i., when rounding of cells was clearly observed. The difference in titres may be due to timing, as virus titres for SHK-1 [9] and TO cells [27] were determined on day 8 and 12 p.i. respectively. Although virus titres were lower, we have documented that primary epithelial cell cultures have the potential to be used for study of ISA pathogenesis and ISAV transmission mechanisms.

\section{Conclusion}

In summary, this study constitutes the first documentation of ISAV infection of gill epithelial cells, in vivo and in vitro, and provides evidence of the gill as a potential port of entry for ISAV. The Atlantic salmon primary gill epithelial cells described here were used to study ISAV 


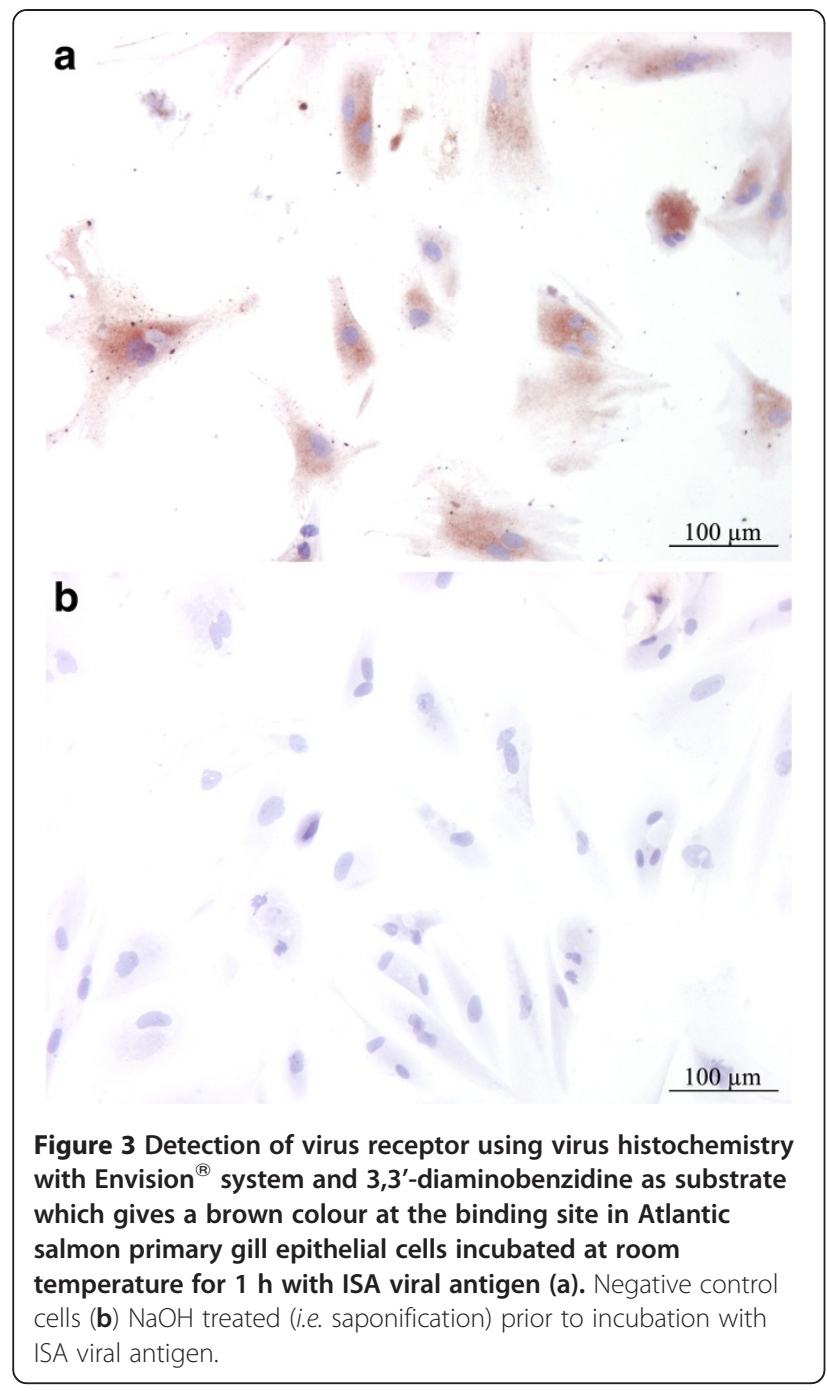

cell tropism and infection. The cells are not a new cell line, and not optimal for maximum yield of pathogenic ISAV strains. Also, attempts to passage the cells were unsuccessful. However, they are of interest for two reasons. Firstly, they possess epithelial characteristics and express ISAV 4-O-acetylated sialic acids receptors critical for ISAV infection. Secondly, they provide further evidence that Atlantic salmon gill epithelial cells could be a target for ISAV. They may also provide a system for working with so far uncultivable gill-infecting agents, $e$. g., low pathogenic ISAV HPRO strains, and also other suspected gill-pathogenic agents such as pox virus [47].

\section{Materials and methods}

\section{Preparation of primary gill epithelial cells}

Primary cultures of gill epithelial cells from juvenile Atlantic salmon $(5-10 \mathrm{~g})$ were isolated as previously described [48], with some modifications. Briefly, fish were euthanized by anaesthetic overdose in ethyl 3-aminobenzoate
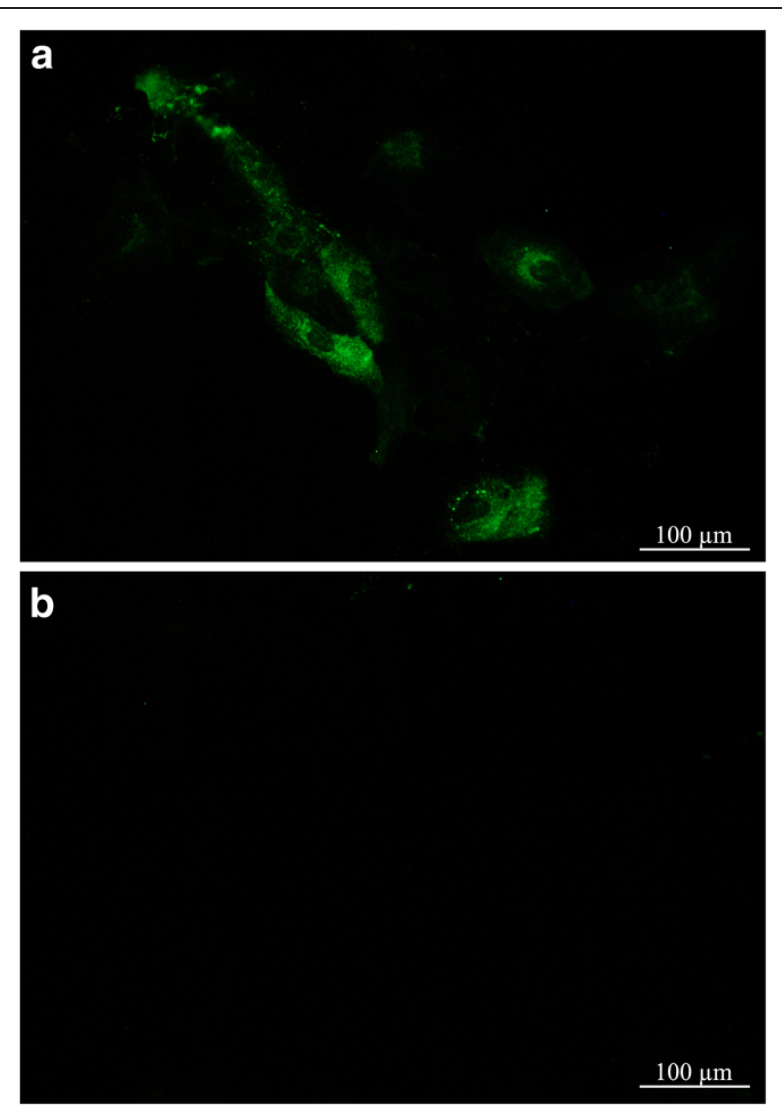

Figure $\mathbf{4}$ Localisation of ISAV in Atlantic salmon primary gill epithelial cells. Infected cells (a) fixed at 4 day p.i. and subjected to immunofluorescence (IFAT) staining (green fluorescent staining) with mouse monoclonal antibody directed against the ISAV nucleoprotein. No viral antigen was detected in mock-infected cells (b).

methanesulfonate salt (Sigma-Aldrich), gill arches excised, washed in phosphate buffer saline (PBS) without $\mathrm{Ca}_{2}^{+}$ and $\mathrm{Mg}_{2}^{+}$containing $200 \mu \mathrm{g} / \mathrm{mL}$ Penicillin/Streptomycin (Invitrogen), $400 \mu \mathrm{g} / \mathrm{mL}$ gentamicin sulfate (Lonza), and $2.5 \mu \mathrm{g} / \mathrm{mL}$ Amphotericin B (Lonza). Cultures were prepared from filaments utilising three cycles of enzymatic digestion with trypsin-EDTA (Lonza), and cell washing in PBS supplemented with $2 \%$ foetal bovine serum (FBS). Cells were re-suspended in L-15 medium supplemented with FBS (20\%), Penicillin/Streptomycin $(100 \mu \mathrm{g} / \mathrm{mL})$, ß-mercaptoethanol (1 $\mathrm{mM})$, nonessential amino acid $(0.1 \mathrm{mM})$, L-glutamine $(2 \mathrm{mM})$ and seeded on 24 well plates at $15^{\circ} \mathrm{C}$. To monitor growth characteristics, cells were observed daily by light microscopy and assessed for viability by trypan-blue exclusion [44], morphology and susceptibility to ISAV infection.

\section{Virus}

The highly pathogenic Norwegian ISAV strain Glesvaer/2/ 90 [8] was propagated in ASK-II cells [25] in Leibovitz L-15 medium (L-15) supplemented with 10\% FBS, glutamine 
Table 1 Differential permissiveness of Atlantic salmon primary gill epithelial cells, ASK-II, SHK-1, and TO cells to ISAV infection

\begin{tabular}{|c|c|}
\hline Cells & tISA virus titres $\left(\mathrm{TCID}_{50} / \mathrm{mL}\right)$ \\
\hline Atlantic salmon primary gill epithelial cells & $1.0 \times 10^{5}$ \\
\hline$\overline{\text { ASK-II }}$ & $1.0 \times 10^{7}$ \\
\hline SHK-1 & $4.0 \times 10^{5}$ \\
\hline$\overline{\mathrm{TO}}$ & $1.0 \times 10^{6}$ \\
\hline
\end{tabular}

Note: $\uparrow$ Titres at 4 days p.i.

(4 mM), and gentamicin $(50 \mu \mathrm{g} / \mathrm{ml})$ at $20^{\circ} \mathrm{C}$. The virus was used for in vivo (fish immersion experiments), for in vitro infection of the primary gill epithelial cells, and for preparation of ISAV antigen for virus histochemistry as previously described [33]. Unless otherwise stated, primary gill epithelial cells with the fluid overlay removed were inoculated with virus at a multiplicity of infection of 0.1 in L-15 with $2 \%$ FBS. Infectivity titrations were done by end point titration in 96-well culture plates as previously described [9].

\section{Experimental infection and fish sampling}

The infection experiment was performed at the Norwegian Veterinary Institute in freshwater tanks at $8^{\circ} \mathrm{C}$. A total of 31 Atlantic salmon presmolts $(20 \mathrm{~g})$ confirmed free of ISAV, infectious pancreatic necrosis (IPNV), proliferative kidney disease (PKD) and Salmonid alpha virus (SAV) by RT-PCR analysis were used. Fish were challenged by immersion (bath) for 3 hours with $10^{4} \mathrm{TCID}_{50}$ per ml. Uninfected control fish were kept in a separate tank. Three five fish were sampled at 8 h, 24 h, 48 h, 8 days and 20 days post infection (p.i.), and gill tissues collected in buffered $4 \%$ formaldehyde. Fish were anesthetized with methane tricaine sulphonate (MS222, Sigma, $0.1 \mathrm{mg} / \mathrm{mL}$ ) before handling.

\section{Ethical considerations}

Fish sampling for preparation of primary gill epithelial cells and experimental infection were preformed according to internationally recognized ethical guidelines. The experiments were approved by The Norwegian Animal Research Authority (NARA); identification number 2697.

\section{Immunohisto- and cytochemistry}

Immunohistochemistry was performed as previously described [49] on gill samples from in vivo immersion experiments and tissues samples from the Faroe Islands. Briefly, formalin-fixed paraffin-embedded tissue sections were de-waxed and subjected to microwave oven treatment. Rabbit antibody to recombinant ISAV NP [50] and Vectastain ABC-AC kit (Vectastain anti rabbit Ig ABC-AP kit, AK 5001, Vector Laboratories, Inc.) were used for detection, employing Fast Red $(1 \mathrm{mg} / \mathrm{ml})$ and Naphtol AS-MX phosphate $(0.2 \mathrm{mg} / \mathrm{ml})$ with $1 \mathrm{mM}$ Levamisole in 0.1 M TBS (pH8.2) as substrate.
Immunocytochemistry was performed to demonstrate purity of the primary gill epithelial cultures as previously described [51]. Briefly, cultures were washed in PBS and fixed in $4 \%$ formaldehyde in PBS for $10 \mathrm{~min}$. Non-specific binding was blocked by incubation in 5\% FBS in PBS for $20 \mathrm{~min}$. Labelling was performed by overnight incubation at $4^{\circ} \mathrm{C}$ with mouse monoclonal anti-cytokeratin (AE1/ AE3) (Invitrogen) diluted 1:50 in PBS with 2\% FBS, followed by $30 \mathrm{~min}$ incubation with HRP-labelled secondary antibody (Envision ${ }^{\circledR}$ K4007; DAKO). 3,3'-diaminobenzidine $(D A B)$ was used as a substrate.

\section{Immunofluorescent labelling}

Immunofluorescent antibody test (IFAT) was used for ISAV detection in infected primary gill epithelial cells as previously described [13], with some modifications. Briefly, 7 day old primary gill cultures were inoculated with ISAV at a multiplicity of infection (MOI) of 0.1 in Leibovitz's L-15 medium with $2 \% \mathrm{FBS}$ and allowed to adsorb for $2 \mathrm{~h}$ at $15^{\circ} \mathrm{C}$. The inoculum was removed and fresh L-15 medium supplemented with FBS (10\%), Penicillin/Streptomycin $(100 \mu \mathrm{g} /$ $\mathrm{mL}), ß$-mercaptoethanol $(1 \mathrm{mM})$, nonessential amino acid (0.1 $\mathrm{mM})$, L-glutamine (2 $\mathrm{mM})$ added and incubated for 4 days. Cultures were washed in PBS, fixed in $80 \%$ acetone for $10 \mathrm{~min}$, and IFAT was performed with anti ISAV haemagglutinin esterase (HE) monoclonal antibody [13] and FITC-labelled goat anti-mouse Ig (Southern Biotech).

\section{Transmission electron microscopy}

Transmission electron microscopy (TEM) was performed on 7-day-old primary gill epithelial cells as previously described [52]. Briefly, cultures were washed in PBS, fixed in $2.5 \%$ glutaraldehyde in $0.5 \mathrm{M}$ cacodylate buffer postfixed in $2 \% \mathrm{OsO}_{4}$ in $0.1 \mathrm{~m}$ cacodylate buffer $\mathrm{pH} 7.2$ for $2 \mathrm{~h}$, dehydrated in ascending concentrations of ethanol and embedded in LX 112 Resin (Ladd Research Industries). Ultra-thin sections were mounted on uncoated copper grids, stained with uranyl acetate and lead citrate using standard methodology before examination.

\section{Virus histochemistry}

For detection of the ISAV 4-O-acetylated sialic acid receptor, virus histochemistry was performed on primary gill cultures as previously described [33]. Briefly, cultures 
were washed in PBS, fixed in 4\% formaldehyde in PBS for $10 \mathrm{~min}$. Labelling was performed by incubating with each of the following for $1 \mathrm{~h}$ : ISAV antigen (100 HAU mL-1), anti ISAV HE monoclonal antibody [13] and HRP-labelled secondary antibody (Envision ${ }^{\circledR}$ K4007; DAKO). DAB was used as a substrate. Cultures were counterstained with Mayer's haematoxylin. To document binding specificity, control cells were de- $O$-acetylated by mild alkaline saponification using $0.1 \mathrm{M}$ sodium hydroxide for $30 \mathrm{~min}$ [46].

\section{ISAV replication assay}

To further characterize ISAV infection of the primary gill epithelial cells, comparisons of ISAV replication in primary gill epithelial cells were made with ASK-II, SHK-1 and TO cells. Cultures of primary gill epithelial cells, ASK-II, SHK-1 and TO cells were inoculated with ISAV as previously described, and incubated for 4 days. Supernatants were collected four days p.i., and infectivity titrations performed on ASK-II cells by end point titration in 96well culture plates as previously described [9]. The 50\% tissue culture infective dose $\left(\mathrm{TCID}_{50}\right)$ was estimated by the method of Kärber [53].

\section{Competing interests}

The authors declare that they have no competing interests.

\section{Authors' contributions}

SCW and MA carried out the experiments and drafted the manuscript. KF participated in design and coordination of the experiment, and aided drafting of the manuscript. OBD and EOK participated in coordination and helped to draft the manuscript. All authors read and approved the final manuscript.

\section{Acknowledgements}

The work was supported by Norwegian Research Council (grant no. 186907), The Atlantic innovation Fund, Canada Inc and Novartis Animal Health.

\section{Author details}

${ }^{1}$ Norwegian Veterinary Institute, Ullevålsveien 68, PO Box 750 Sentrum, Oslo $\mathrm{N}-0106$, Norway. ${ }^{2}$ Norwegian School of Veterinary Science, PO Box 8146Dep, $\mathrm{N}-0033$, Oslo, Norway.

Received: 22 August 2012 Accepted: 5 December 2012

Published: 2 January 2013

\section{References}

1. Evensen O, Thorud KE, Olsen YA: A morphological study of the gross and light microscopic lesions of infectious anaemia in atlantic salmon (salmo salar). Res Vet Sci 1991, 51:215-222.

2. Lovely JE, Dannevig BH, Falk K, Hutchin L, MacKinnon AM, Melville KJ, Rimstad E, Griffiths SG: First identification of infectious salmon anaemia virus in north america with haemorrhagic kidney syndrome. Dis Aquat Organ 1999, 35:145-148.

3. Mullins JED, Groman D, Wadowska D: Infectious salmon anaemia in salt water Atlantic salmon (salmo salar L.) in New Brunswick, Canada. B Eur Assoc Fish Pat 1998, 18:110-114.

4. Rodger HD, Richards RH: Haemorrhagic smolt syndrome: a severe anaemic condition in farmed salmon in scotland. Vet Rec 1998, 142:538-541.

5. Bouchard DA, Brockway K, Giray C, Keleher W, Merrill PL: First report of infectious salmon anemia (ISA) in the united states. B Eur Assoc Fish Pat 2001, 21:86-88.

6. Godoy MG, Aedo A, Kibenge MJ, Groman DB, Yason CV, Grothusen H, Lisperguer A, Calbucura M, Avendano F, Imilan M, et al: First detection, isolation and molecular characterization of infectious salmon anaemia virus associated with clinical disease in farmed atlantic salmon (salmo salar) in chile. BMC Vet Res 2008, 4:28.

7. Bouchard D, Keleher W, Opitz HM, Blake S, Edwards KC, Nicholson BL: Isolation of infectious salmon anemia virus (ISAV) from atlantic salmon in New brunswick canada. Dis Aquat Organ 1999, 35:131-137.

8. Dannevig BH, Falk K, Press CM: Propagation of infectious salmon anaemia (ISA) virus in cell culture. Vet Res 1995, 26:438-442.

9. Falk K, Namork E, Rimstad E, Miaaland S, Dannevig BH: Characterization of infectious Salmon anemia virus, an orthomyxo-like virus isolated from atlantic Salmon (salmo salar L.). J Virol 1997, 71:9016-9023.

10. Hovland T, Nylund A, Watanabe K, Endresen C: Observation of infectious salmon anemia virus in atlantic salmon, salmo-salar l. J Fish Dis 1994, 17:291-296.

11. Koren CWR, Nylund A: Morphology and morphogenesis of infectious salmon anaemia virus replicating in the endothelium of atlantic salmon salmo salar. Dis Aquat Organ 1997, 29:99-109.

12. Aspehaug V, Mikalsen $A B$, Snow M, Biering E, Villoing $S$ : Characterization of the infectious salmon anemia virus fusion protein. J Virol 2005, 79:12544-12553.

13. Falk K, Namork E, Dannevig BH: Characterization and applications of a monoclonal antibody against infectious salmon anaemia virus. Dis Aquat Organ 1998, 34:77-85.

14. Falk K, Aspehaug V, Vlasak R, Endresen C: Identification and characterization of viral structural proteins of infectious salmon anemia virus. J Virol 2004, 78:3063-3071.

15. Hellebø A, Vilas U, Falk K, Vlasak R: Infectious salmon anemia virus specifically binds to and hydrolyzes 4-O-acetylated sialic acids. J Virol 2004, 78:3055-3062.

16. Biering E, Falk K, Hoel E, Thevarajan J, Joerink M, Nylund A, Endresen C, Krossøy B: Segment 8 encodes a structural protein of infectious salmon anaemia virus (ISAV); the colinear transcript from segment 7 probably encodes a non-structural or minor structural protein. Dis Aquat Organ 2002, 49:117-122.

17. Clouthier SC, Rector T, Brown NE, Anderson ED: Genomic organization of infectious salmon anaemia virus. J Gen Virol 2002, 83:421-428.

18. Krossøy B, Devold M, Sanders L, Knappskog PM, Aspehaug V, Falk K, Nylund A, Koumans S, Endresen C, Biering E: Cloning and identification of the infectious salmon anaemia virus haemagglutinin. J Gen Virol 2001, 82:1757-1765

19. Krossøy B, Hordvik I, Nilsen F, Nylund A, Endresen C: The putative polymerase sequence of infectious salmon anemia virus suggests a new genus within the orthomyxoviridae. J Virol 1999, 73:2136-2142.

20. Mjaaland S, Rimstad E, Falk K, Dannevig BH: Genomic characterization of the virus causing infectious Salmon anemia in atlantic Salmon (salmo salar L.): an orthomyxo-like virus in a teleost. J Virol 1997, 71:7681-7686.

21. Rimstad E, Mjaaland S, Snow M, Mikalsen AB, Cunningham CO: Characterization of the infectious salmon anemia virus genomic segment that encodes the putative hemagglutinin. J Virol 2001, 75:5352-5356.

22. Snow M, Cunningham CO: Characterisation of the putative nucleoprotein gene of infectious salmon anaemia virus (ISAV). Virus Res 2001, 74:111-118.

23. Snow M, Ritchie RJ, Arnaud O, Villoing S, Aspehaug V, Cunningham CO: Isolation and characterisation of segment 1 of the infectious salmon anaemia virus genome. Virus Res 2003, 92:99-105.

24. Dannevig $B H$, Falk $K$, Namork E: Isolation of the causal virus of infectious salmon anaemia (ISA) in a long-term cell line from atlantic salmon head kidney. J Gen Virol 1995, 76(Pt 6):1353-1359.

25. Devold M, Krossøy B, Aspehaug V, Nylund A: Use of RT-PCR for diagnosis of infectious salmon anaemia virus (ISAV) in carrier sea trout salmo trutta after experimental infection. Dis Aquat Organ 2000, 40:9-18.

26. Kibenge FSB, Lyaku JR, Rainnie D, Hammell KL: Growth of infectious salmon anaemia virus in CHSE-214 cells and evidence for phenotypic differences between virus strains. J Gen Virol 2000, 81:143-150

27. Wergeland HI, Jakobsen RA: A salmonid cell line (TO) for production of infectious salmon anaemia virus (ISAV). Dis Aquat Organ 2001, 44:183-190.

28. Goss GG, Perry SF, Wood CM, Laurent P: Mechanisms of lon and acid-base regulation at the gills of fresh-water fish. J Exp Zool 1992, 263:143-159.

29. Hughes GM: An introduction to the study of gills. In Gills. Edited by Houlihan DF, Rankin JC, Shuttleworth TJ. New York: Cambridge University Press; 1982:1-24.

30. Evans DH, Piermarini PM, Choe KP: The multifunctional fish gill: dominant site of gas exchange, osmoregulation, acid-base regulation, and excretion of nitrogenous waste. Phys Rev 2005, 85:97-177. 
31. Mikalsen AB, Teig A, Helleman AL, Mjaaland S, Rimstad E: Detection of infectious salmon anaemia virus (ISAV) by RT-PCR after cohabitant exposure in atlantic salmon salmo salar. Dis Aquat Organ 2001, 47:175-181.

32. Moneke EE, Groman DB, Wright GM, Stryhn H, Johnson GR, Ikede BO, Kibenge FSB: Correlation of virus replication in tissues with histologic lesions in atlantic salmon experimentally infected with infectious salmon anemia virus. Vet Pathol 2005, 42:338-349.

33. Aamelfot M, Dale OB, Weli SW, Koppang EO, Falk K: Expression of the ISAV receptor on Atlantic salmon endothelial cells correlates with cell tropism of ISAV. J Virol 2012, 86(19):10571-10578.

34. Christiansen DH, Østergaard PS, Snow M, Dale OB, Falk K: A low-pathogenic variant of infectious salmon anemia virus (ISAV-HPRO) is highly prevalent and causes a non-clinical transient infection in farmed atlantic salmon (salmo salar L.) in the faroe islands. J Gen Virol 2011, 92:909-918.

35. Lyngstad TM, Hjortaas MJ, Kristoffersen AB, Markussen T, Karlsen ET, Jonassen CM, Jansen PA: Use of molecular epidemiology to trace transmission pathways for infectious salmon anaemia virus (ISAV) in norwegian salmon farming. Epidemics 2011, 3:1-11.

36. Bergelson JM: Virus interactions with mucosal surfaces: alternative receptors, alternative pathways. Curr Opin Microbiol 2003, 6:386-391.

37. Matrosovich MN, Matrosovich TY, Gray T, Roberts NA, Klenk HD: Human and avian influenza viruses target different cell types in cultures of human airway epithelium. Proc Natl Acad Sci US A 2004, 101:4620-4624.

38. Thompson Cl, Barclay WS, Zambon MC, Pickles RJ: Infection of human airway epithelium by human and avian strains of influenza a virus. J Virol 2006, 80:8060-8068

39. Shinya K, Ebina M, Yamada S, Ono M, Kasai N, Kawaoka Y: Influenza virus receptors in the human airway. Nature 2006, 440:435-436.

40. Nicholls JM, Chan MCW, Chan WY, Wong HK, Cheung CY, Kwong DLW, Wong MP, Chui WH, Poon LLM, Tsao SW, et al: Tropism of avian influenza a (H5N1) in the upper and lower respiratory tract. Nat Med 2007, 13:147-149.

41. Chan MCW, Chan RWY, Yu WCL, Ho CCC, Yuen KM, Fong JHM, Tang LLS, Lai WW, Lo ACY, Chui WH, et al: Tropism and innate host responses of the 2009 pandemic H1N1 influenza virus in ex vivo and in vitro cultures of human conjunctiva and respiratory tract. Am J Pathol 2010, 176:1828-1840.

42. Schnittler HJ, Mahner F, Drenckhahn D, Klenk HD, Feldmann H: Replication of marburg virus in human endothelial cells. a possible mechanism for the development of viral hemorrhagic disease. J Clin Invest 1993 , 91:1301-1309.

43. Belser JA, Wadford DA, Xu JG, Katz JM, Tumpey TM: Ocular infection of mice with influenza a $(\mathrm{H} 7)$ viruses: a site of primary replication and spread to the respiratory tract. J Virol 2009, 83:7075-7084.

44. Parolini M, Quinn B, Binelli A, Provini A: Cytotoxicity assessment of four pharmaceutical compounds on the zebra mussel (dreissena polymorpha) haemocytes, gill and digestive gland primary cell cultures. Chemosphere 2011, 84:91-100

45. Ernst SA, Dodson WC, Karnaky KJ Jr: Structural diversity of occluding junctions in the low-resistance chloride-secreting opercular epithelium of seawater-adapted killifish (fundulus heteroclitus). J cell biol 1980, 87:488-497.

46. Reuter G, Schauer R: Determination of Sialic Acids. Method Enzymol 1994 230:168-199.

47. Nylund A, Watanabe K, Nylund S, Karlsen M, Saether PA, Arnesen CE, Karlsbakk E: Morphogenesis of salmonid gill poxvirus associated with proliferative gill disease in farmed atlantic salmon (salmo salar) in norway. Arch Virol 2008, 153:1299-1309.

48. Butler R, Nowak BF: A dual enzyme method for the establishment of longand medium-term primary cultures of epithelial and fibroblastic cells from atlantic salmon gills. J Fish Biol 2004, 65:1108-1125.

49. Hetland DL, Dale OB, Skj>dt K, Press CM, Falk K: Depletion of CD8 alpha cells from tissues of atlantic salmon during the early stages of infection with high or low virulent strains of infectious salmon anaemia virus (ISAV). Dev Comp Immunol 2011, 35:817-826.

50. Aspehaug V, Falk K, Krossøy B, Thevarajan J, Sanders L, Moore L, Endresen C, Biering E: Infectious salmon anemia virus (ISAV) genomic segment 3 encodes the viral nucleoprotein (NP), an RNA-binding protein with two monopartite nuclear localization signals (NLS). Virus Res 2004, 106:51-60.
51. Shimonishi M, Hatakeyama J, Sasano Y, Takahashi N, Uchida T, Kikuchi M, Komatsu M: In vitro differentiation of epithelial cells cultured from human periodontal ligament. J Periodontal Res 2007, 42:456-465.

52. Koppang EO, Haugarvoll E, Hordvik I, Aune L, Poppe TT: Vaccine-associated granulomatous inflammation and melanin accumulation in atlantic Salmon, salmo salar L., White muscle. J Fish Dis 2005, 28:13-22.

53. Kärber G: Beitrag zur kollektiven behandlung pharmakologischer reihenversuche. Arch Exp Pathol Pharmakol 1931, 162:480-483.

doi:10.1186/1743-422X-10-5

Cite this article as: Weli et al:: Infectious salmon anaemia virus infection of Atlantic salmon gill epithelial cells. Virology Journal 2013 10:5.

\section{Submit your next manuscript to BioMed Central and take full advantage of:}

- Convenient online submission

- Thorough peer review

- No space constraints or color figure charges

- Immediate publication on acceptance

- Inclusion in PubMed, CAS, Scopus and Google Scholar

- Research which is freely available for redistribution 